Article

\title{
Anthocyanins of Coloured Wheat Genotypes in Specific Response to SalStress
}

\author{
Sonia Mbarki ${ }^{1,2, \dagger}$, Oksana Sytar ${ }^{3,4, *,+}$, Marek Zivcak ${ }^{4}$ (i) , Chedly Abdelly ${ }^{2}$, Artemio Cerda 5 (D) \\ and Marian Brestic 4 (iD \\ 1 National Research Institute of Rural Engineering, Water and Forests (INRGREF), BP 10, Aryanah 2080, \\ Tunisia; mbarkisonia14@gmail.com \\ 2 Laboratory of Plant Extremophiles, Biotechnology Center at the Technopark of Borj-Cedria Tunisia, BP 901, \\ Hammam Lif 2050, Tunisia; chedly.abdelly@cbbc.rnrt.tn \\ 3 Department of Plant Biology, Institute of Biology, Kiev National University of Taras Shevchenko, \\ Volodymyrska St, 64, 02000 Kyiv, Ukraine; oksana.sytar@gmail.com \\ 4 Department of Plant Physiology, Slovak University of Agriculture, Nitra, Tr. A. Hlinku 2, 94901 Nitra, \\ Slovak Republic; marek.zivcak@uniag.sk (M.Z.); marian.brestic@uniag.sk (M.B.) \\ 5 Departament of Geografy, University of València, Blasco Ibàñez, 28, 46010 Valencia, Spain; \\ artemio.cerda@uv.es \\ * Correspondence: oksana.sytar@gmail.com; Tel.: +421-37-3414-822 \\ + Sonia Mbarki and Oksana Sytar equally contributed to this work.
}

Received: 16 May 2018; Accepted: 21 June 2018; Published: 23 June 2018

\begin{abstract}
The present study investigated the effect of salt stress on the development of adaptive responses and growth parameters of different coloured wheat genotypes. The different coloured wheat genotypes have revealed variation in the anthocyanin content, which may affect the development of adaptive responses under increasing salinity stress. In the early stage of treatment with salt at a lower $\mathrm{NaCl}$ concentration $(100 \mathrm{mM})$, anthocyanins and proline accumulate, which shows rapid development of the stress reaction. A dose-dependent increase in flavonol content was observed for wheat genotypes with more intense purple-blue pigmentation after treatment with $150 \mathrm{mM}$ and $200 \mathrm{mM} \mathrm{NaCl}$. The content of $\mathrm{Na}^{+}$and $\mathrm{K}^{+}$obtained at different levels of salinity based on dry weight (DW) was more than 3 times greater than the control, with a significant increase of both ions under salt stress. Overall, our results demonstrated that coloured wheat genotypes with high anthocyanin content are able to maintain significantly higher dry matter production after salt stress treatment.
\end{abstract}

Keywords: salinity; anthocyanins; proline; MDA; flavonol; wheat

\section{Introduction}

Land degradation has become currently a strong issue at a global level as its spatial distribution varies from 1 billion ha to over 6 billion ha [1]. Climate change, high salt levels in soils and irrigation waters are major environmental concerns, and a problem for agriculture in many arid and semi-arid regions [2]. Approximately 15\% of the cultivated land has an excess of salt [3], and large quantities of water are of very poor quality. Globally, no less than 10 million hectares of agricultural land are abandoned annually because of salinity. Salt-induced land degradation is a very important issue affecting the status of food productivity worldwide [2-4].

Salinity can increase the toxic levels of some ions and cause water stress and malnutrition in plants. The difference in salt tolerance may be connected with plant ontogenetic stages and plant species. It is usually visible in the reduction of biomass and yield or in decreasing survival rates $[5,6]$. In plants, osmotic stress and ionic toxicity are two stresses that follow salinity and can be destructive under 
prolonged treatment [5]. Plants respond to these variations in soil salinity by provoking resistance mechanisms [7,8]. Among known mechanisms, osmotic adjustment plays a major role in plant tolerance to stress [9]. A high level of $\mathrm{Na}^{+}$compromises carbon fixation, which supports an over-reduction of light-harvesting complexes, reducing photosynthesis and the production of reactive oxygen (ROS) [10]. This process generates a disturbance in ionic homeostasis and/or nutritional imbalance [11].

Under stress conditions, secondary metabolite accumulation often occurs in plants [12]. Secondary metabolites may participate as signal molecules and some specific elicitors. Ionic and osmotic stresses, which are part of salt stress in plants, stimulate the accumulation or decrease of specific secondary metabolites in plants [13]. Anthocyanins are increased during the salt stress response [14]. At the same time, salt stress is able to decrease the level of anthocyanins in salt-sensitive plant species [14]. Flavonoids are one of the largest groups of plant phenolics that participate in plant defence [15] via an effective strategy against ROS [16]. Under salt stress, Azospirillum brasilense showed higher secretion of nod-gene-inducing flavonoid species and improved root branching in the seedling roots of bean plants [17]. Other salt-sensitive crops like potato, eggplant, pepper, cabbage, lettuce, rise and maize shows their sensitivity to hyperosmotic stresses by the rise of phenolics, as well [18-21]. Under drought and salinity stresses, wheat plants raise antioxidant defence mechanisms under abiotic stresses to alleviate oxidative damage [22,23].

It was suggested that accession-dependent capacity to stimulate salt-stress response antioxidative mechanisms may affect a corresponding changeability for the growth sustainability of some plants. The high leaf antioxidant activity and total phenolic content have been estimated in the halophyte Cakile maritima leaves [24]. The wheat genotypes demonstrated a wide range of responses to high salinity stress during the growth stages [25]. The effect of salt stress on wheat plants is one of the most serious problems in arid and semi-arid regions, which reduces both the quantity and quality of the production of this cereal [26].

The response to the salt stress of plant species depends on the plant species and varieties, salt concentration, growing conditions and stage of development of the plant. The identification of salt-tolerant varieties can positively develop the production of areas at risk or irrigated with salinized water and would be of obvious interest in helping to improve varieties.

Therefore, the purpose of this work was to study the effect of salt stress on the development of adaptive responses and growth parameters of different wheat cultivars (coloured and not coloured) to estimate parameters that can help to choose salt-tolerant wheat cultivars.

\section{Results}

\subsection{SFR, ANTH, FLAV and MFI}

The results of the presented experimental work showed that the SFR values at the first stage of treatment with a concentration of $100 \mathrm{mM}$ increased in two genotypes, Citrus yellow and PS Karkulka. Under $150 \mathrm{mM} \mathrm{NaCl}$, increasing SFR values have been observed in the non-coloured genotypes (Citrus yellow) at the first stage of treatment and continue in the second stage of treatment. For the two coloured genotypes, KM 178-14 purple and Skorpion Blue aleurone under the first stage of treatment with $100 \mathrm{mM}$ and $150 \mathrm{mM} \mathrm{NaCl}$ showed no significant changes compared to the control. At the second stage of treatment, with increasing salt concentration (150 mM and $200 \mathrm{mM} \mathrm{NaCl})$, the SFR value decreased (Figure 1).

Flavonol accumulation, which is also part of the adaptive reaction to salt stress, was observed slightly after the first stage of treatment with $\mathrm{NaCl}$ concentrations of $100 \mathrm{mM}$ and $150 \mathrm{mM}$. At the second stage of treatment with $150 \mathrm{mM}$ and $200 \mathrm{mM} \mathrm{NaCl}$, there was a significant difference in the flavonol reaction between the non-coloured and coloured wheat genotypes (Figure 2A). A dose-dependent increase in flavonol content was observed for the KM 178-14 purple and Skorpion Blue aleurone wheat genotypes after treatment with $150 \mathrm{mM}$ and $200 \mathrm{mM} \mathrm{NaCl}$, respectively (Figure 2B). 

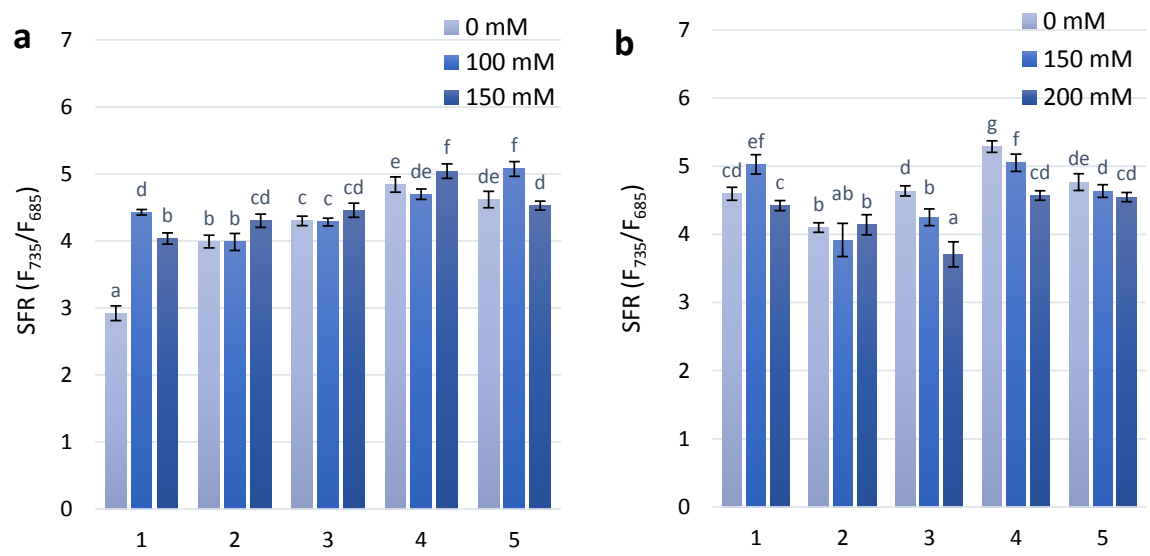

Figure 1. Values of SFR (simple fluorescence ratio) in the leaves of wheat plant genotypes exposed to salt stress during 30 days after seedlings (a) - first stage of treatment; (b) - second stage of treatment. The numbers indicate individual cultivars of wheat as follow: 1-Citrus yellow, 2-KM 53-14 Blue, 3-KM 178-14 purple, 4-Skorpion Blue aleurone, 5-PS Karkulka purple. The columns represent the mean values \pm S.E. for six replicates. Statistically significant differences among treatments at each time are indicated by different small letters (Duncan test, $p<0.05$ ).
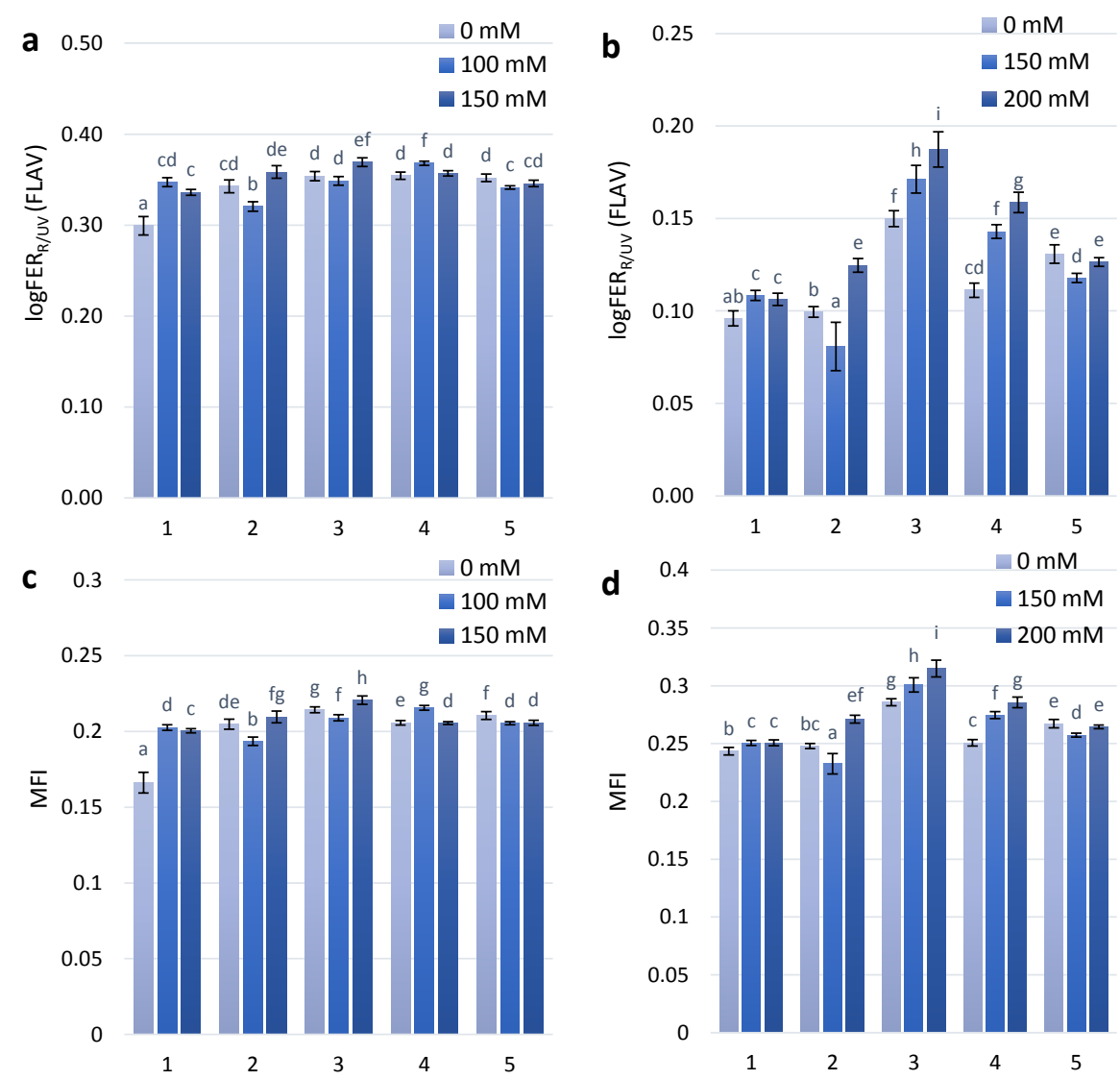

Figure 2. Flavonols accumulation (logFERR/UV-FLAV) in the leaves of investigated wheat plant genotypes exposed to salt stress during 30 days after seedlings (a)—first stage of treatment; (b) - second stage of treatment. MFI parameter in the leaves of investigated wheat plant genotypes exposed to salt stress during 30 days after seedlings (c) - first stage of treatment; (d) - second stage of treatment.The numbers shown individual cultivars of wheat: 1-Citrus yellow, 2-KM 53-14 Blue, 3-KM 178-14 purple, 4-Skorpion Blue aleurone, 5-PS Karkulka purple The columns represent the mean values \pm S.E. for six replicates. Statistically significant differences among treatments at each time are indicated by different small letters (Duncam test, $p<0.05$ ). 
The modified flavonoid index (MFI), which takes into consideration the accumulation of both flavonols and anthocyanins, is a better estimate of flavonoids than FLAV. The results of statistical analyses using MFI are highly similar to those that use biochemical analysis data [27]. The MFI index showed a similar dose-dependent tendency as the FLAV index after the second stage of treatment (Figure 2D).

\subsection{Anthocyanins Content}

The experimental wheat genotypes have been characterized by different anthocyanin contents (Figure 3), which could affect the specific development of adaptive responses to increasing salinity stress [25].
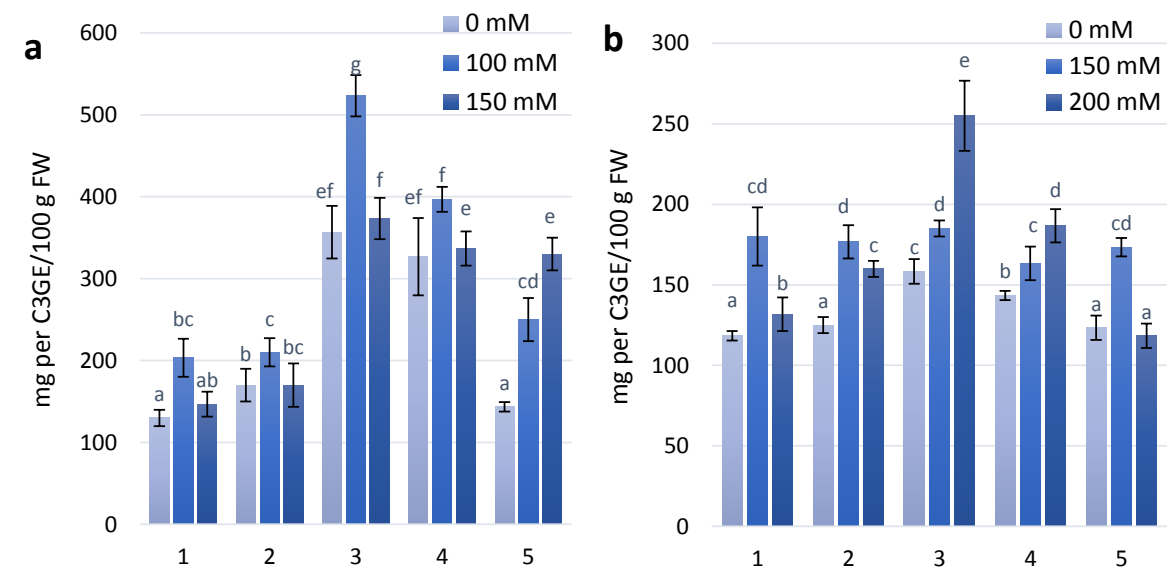

Figure 3. Anthocyanins content in wheat leaves under effect of different $\mathrm{NaCl}$ concentrations (a)-first stage of treatment; (b) - second stage of treatment. Wheat genotypes: 1-Citrus yellow, 2-KM 53-14 Blue, 3-KM 178-14 purple, 4-Skorpion Blue aleurone, 5-PS Karkulka purple. The columns represent the mean values \pm S.E. for six replicates. Statistically significant differences among treatments at each time are indicated by different small letters (Duncan test, $p<0.05$ ).

Coloured plant genotypes that have high anthocyanin content are a good object to study abiotic tolerance, especially salt-tolerant traits. Two wheat genotypes, KM 178-14 purple and Skorpion Blue aleurone, had the highest anthocyanin content in the leaves among all experimental variants. At the first stage of the experimental treatment with $100 \mathrm{mM} \mathrm{NaCl}$, increasing anthocyanin content was observed in almost all experimental variants. Under treatment with $150 \mathrm{mM} \mathrm{NaCl}$, anthocyanin content was similar to the control level in all experimental variants, except for the wheat genotype PS Karkulka. The higher content of anthocyanins did not result in development of the same adaptation to salt stress in the genotypes. At the second stage of the experimental treatment, genotypes (KM 178-14 purple and Skorpion Blue aleurone) with higher anthocyanin content at $100 \mathrm{mM} \mathrm{NaCl}$ had no changes in anthocyanin content. The genotype KM 178-14 purple showed a significant increase in anthocyanin content of $30 \%$ at $200 \mathrm{mM} \mathrm{NaCl}$ compared to the control. Other genotypes (Citrus yellow, KM 53-14 Blue and PS Karkulka) have been characterized by an increase in anthocyanins at $150 \mathrm{mM} \mathrm{NaCl}$, but at $200 \mathrm{mM} \mathrm{NaCl}$, they were similar to the level of the control.

\subsection{Proline Content}

The results of the presented experimental work found that wheat genotypes characterized by increased anthocyanin content in the first and second stages of salt treatment show increasing proline content. In the first stage, a significant increase in proline content was observed for the wheat genotype KM 178-14 purple (Figure 4A). Under the second stage of treatment with $100 \mathrm{mM} \mathrm{NaCl}$, a significant increase in proline content was observed for the KM 53-14 Blue and KM 178-14 purple wheat genotypes. However, under the $200 \mathrm{mM} \mathrm{NaCl}$ treatment in the second stage of treatment, 
all experimental genotypes showed increased proline content, especially the coloured cultivars KM 178-14 purple and Skorpion Blue aleurone (Figure 4B).
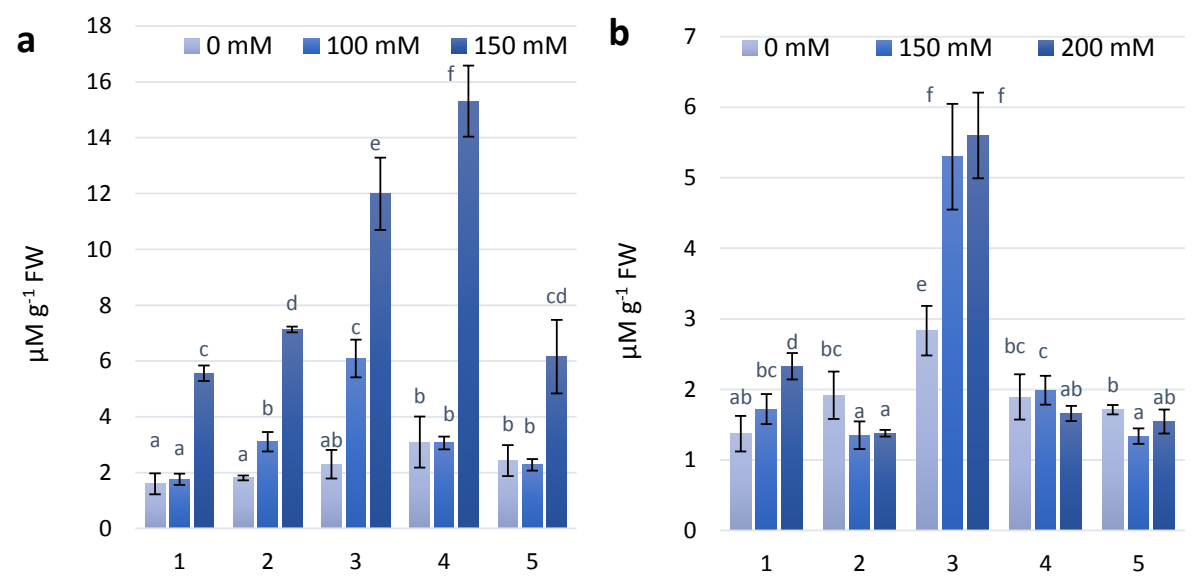

Figure 4. Proline content in wheat leaves under effect of different $\mathrm{NaCl}$ concentrations (a) - first stage of treatment; (b) - second stage of treatment. Wheat genotypes: 1-Citrus yellow, 2-KM 53-14 Blue, 3-KM 178-14 purple, 4-Skorpion Blue aleurone, 5-PS Karkulka purple. The columns represent the mean values \pm S.E. for six replicates. Statistically significant differences among treatments at each time are indicated by different small letters (Duncan test, $p<0.05$ ).

\subsection{Lipid Peroxidation Assay}

Lipid peroxidation (LP) is a biochemical marker for ROS-mediated damage. MDA is one of the better known secondary metabolite of LP [28,29]. The results of the experimental work consisting of two stages of $\mathrm{NaCl}$ treatment have shown the tendency to increase the MDA level in KM 53-14 Blue and KM 178-14 purple wheat genotypes, whereas other wheat genotypes were almost on a control level after the first treatment (Figure 5A). The significant increase of MDA accumulation was observed in the second treatment with concentration of $200 \mathrm{mM} \mathrm{NaCl}$ in all experimental variants (Figure 5B). Under the concentration $100 \mathrm{mM}$, almost all experimental variants have been characterized by MDA content equal to the control level, except of the genotypes Skorpion Blue aleurone and PS Karkula purple, in which we observed the decreasing tendency of MDA.
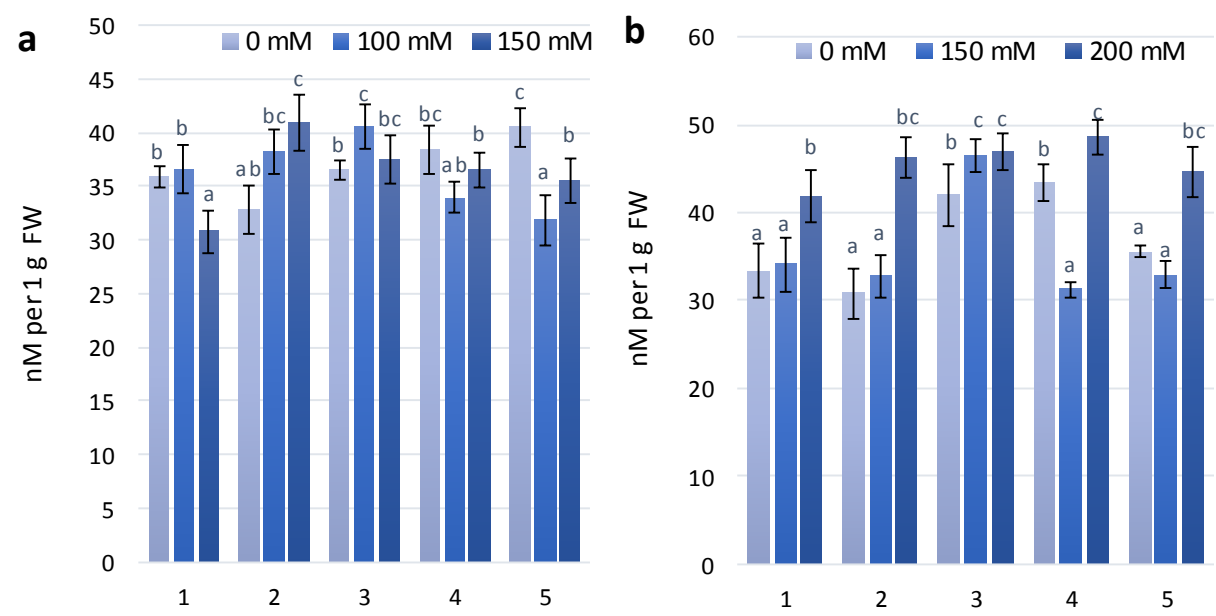

Figure 5. MDA content in wheat leaves under effect of different $\mathrm{NaCl}$ concentrations (a) - first stage of treatment; (b)—second stage of treatment. Wheat genotypes: 1-Citrus yellow, 2-KM 53-14 Blue, 3-KM 178-14 purple, 4-Skorpion Blue aleurone, 5-PS Karkulka purple. The columns represent the mean values \pm S.E. for six replicates. Statistically significant differences among treatments at each time are indicated by different small letters (Duncan test, $p<0.05$ ). 


\subsection{Plant Biomass}

It has been suggested that stimulation of antioxidative responses under salt stress may result in comparable variability in growth sustainability [23]. An increase in the dry weight of roots under both concentrations of $\mathrm{NaCl}$ treatment was observed for the wheat genotype KM 178-14 purple. At a concentration of $200 \mathrm{mM} \mathrm{NaCl}$, a higher dry weight was observed more than two times compared to the control for genotypes KM 178-14 purple, Skorpion blue aleurone, PS Karkulka (Table 1). These genotypes were also characterized by a high anthocyanin content in the control variants and different anthocyanin changes during the development of salt stress (Figure 2). The presence of anthocyanins as antioxidants can partly affect the development of stress adaptation responses under salt stress.

Table 1. Fresh and dry mass after salt stress influence.

\begin{tabular}{|c|c|c|c|c|c|c|}
\hline \multirow{3}{*}{ Wheat genotypes } & \multicolumn{3}{|c|}{ Fresh Weight ${ }^{1}$} & \multicolumn{3}{|c|}{ Dry Weight ${ }^{1}$} \\
\hline & \multicolumn{6}{|c|}{ Roots } \\
\hline & Control & $150 \mathrm{mM}$ & $200 \mathrm{mM}$ & Control & $150 \mathrm{mM}$ & $200 \mathrm{mM}$ \\
\hline Citrus Yellow & $0.048 \pm 0.019^{a b}$ & $0.069+0.023^{a}$ & $0.23 \pm 0.07^{b}$ & $0.028 \pm 0.009^{a}$ & $0.019 \pm 0.003^{a b}$ & $0.017 \pm 0.009^{b}$ \\
\hline KM 53-14 Blue & $0.056 \pm 0.003^{b}$ & $0.042 \pm 0.004^{\mathrm{a}}$ & $0.086 \pm 0.02^{c}$ & $0.011 \pm 0.005^{\mathrm{a}}$ & $0.015 \pm 0.002^{\mathrm{a}}$ & $0.016 \pm 0.008^{a}$ \\
\hline KM 178-14 Purple & $0.042 \pm 0.001^{\mathrm{a}}$ & $0.050 \pm 0.016^{a}$ & $0.13 \pm 0.05^{\mathrm{b}}$ & $0.006 \pm 0.001^{\mathrm{a}}$ & $0.010 \pm 0.004^{\mathrm{a}}$ & $0.013 \pm 0.006^{\mathrm{a}}$ \\
\hline Skorpion Blue Aleur. & $0.091 \pm 0.022^{\mathrm{a}}$ & $0.038 \pm 0.014^{b}$ & $0.079 \pm 0.025^{\mathrm{a}}$ & $0.007 \pm 0.003^{a}$ & $0.007 \pm 0.001^{\mathrm{a}}$ & $0.020 \pm 0.012^{a}$ \\
\hline \multirow[t]{3}{*}{ PS Karkulka } & $0.046 \pm 0.012^{b}$ & $0.039 \pm 0.014^{b}$ & $0.228 \pm 0.091^{\mathrm{a}}$ & $0.016 \pm 0.006^{\mathrm{ab}}$ & $0.011 \pm 0.002^{b}$ & $0.023 \pm 0.007^{a}$ \\
\hline & \multicolumn{6}{|c|}{ Shoots } \\
\hline & Control & $150 \mathrm{mM}$ & $200 \mathrm{mM}$ & Control & $150 \mathrm{mM}$ & $200 \mathrm{mM}$ \\
\hline Citrus yellow & $0.278 \pm 0.076^{\mathrm{a}}$ & $0.297 \pm 0.085^{a}$ & $0.233 \pm 0.073^{a}$ & $0.038 \pm 0.011^{\mathrm{ab}}$ & $0.043 \pm 0.014^{\mathrm{a}}$ & $0.019 \pm 0.008^{b}$ \\
\hline KM 53-14 Blue & $0.194 \pm 0.117^{a b}$ & $0.187 \pm 0.028^{a}$ & $0.086 \pm 0.032^{b}$ & $0.028 \pm 0.014^{\mathrm{a}}$ & $0.028 \pm 0.024^{a}$ & $0.018 \pm 0.004^{a}$ \\
\hline KM 178-14 Purple & $0.252 \pm 0.062^{a}$ & $0.188 \pm 0.06^{\mathrm{a}}$ & $0.127 \pm 0.047^{b}$ & $0.032 \pm 0.009^{a}$ & $0.032 \pm 0.012^{\mathrm{ab}}$ & $0.015 \pm 0.007^{b}$ \\
\hline Skorpion Blue Aleur. & $0.556 \pm 0.085^{\mathrm{a}}$ & $0.283 \pm 0.071^{b}$ & $0.079 \pm 0.035^{c}$ & $0.025 \pm 0.009^{\mathrm{a}}$ & $0.042 \pm 0.009^{\mathrm{a}}$ & $0.074 \pm 0.013^{b}$ \\
\hline PS Karkulka & $0.209 \pm 0.069^{\mathrm{a}}$ & $0.241 \pm 0.063^{a}$ & $0.228 \pm 0.052^{\mathrm{a}}$ & $0.030 \pm 0.011^{\mathrm{a}}$ & $0.042 \pm 0.009^{\mathrm{a}}$ & $0.046 \pm 0.015^{a}$ \\
\hline
\end{tabular}

The dry weight of shoot biomass after salt stress influence increased again in Skorpion blue aleurone and PS Karkulka, but for genotype KM 178-14, the purple dry weight of shoots was on the control level. The genotype Citrus yellow, with a lower anthocyanin content, was characterized by a decrease in dry weight under both $\mathrm{NaCl}$ concentrations (150 mM and $200 \mathrm{mM})$. The genotype KM, 53-14 Blue demonstrated decreased shoot dry weight by $45 \%$ compared to the control after treatment with $200 \mathrm{mM} \mathrm{NaCl}$.

\section{6. $\mathrm{Na}^{+}$and $\mathrm{K}^{+}$Level}

The content of $\mathrm{Na}^{+}$and $\mathrm{K}^{+}$obtained at different levels of salinity on the basis of DW was more than 3 times greater than the control, with a significant increase of both ions under salt stress. For some wheat genotypes, a significant increase in $\mathrm{Na}^{+}$and $\mathrm{K}^{+}$was observed under treatment with $150 \mathrm{mM}$ $\mathrm{NaCl}$ (KM 53-14 Blue and KM 178-14 purple) and under treatment with $200 \mathrm{mM} \mathrm{NaCl}$ (Skorpion Blue aleurone and PS Karkulka). The $\mathrm{Na}^{+} / \mathrm{K}^{+}$ratio was decreased in all experimental wheat genotypes (Table 2).

Table 2. Effects of different levels of salinity on total dry weight, shoot water content after 30 days of sowing of investigated wheat cultivars.

\begin{tabular}{|c|c|c|c|c|c|c|}
\hline Wheat Cultivars ${ }^{1}$ & $\begin{array}{l}\text { Salinity Level } \\
(\mathrm{mM} \mathrm{NaCl})\end{array}$ & $\begin{array}{l}\text { Water Content } \\
\left(\mathrm{g} \mathrm{H}_{2} \mathrm{O} \mathrm{g}^{-1} \mathrm{DW}\right)\end{array}$ & $\begin{array}{c}\text { Total Dry } \\
\text { Weight (g/plant) }\end{array}$ & $\begin{array}{c}\mathrm{Na}^{+} \\
\mathrm{mmol} / \mathrm{g} \mathrm{DW}\end{array}$ & $\begin{array}{c}\mathrm{K}^{+} \\
\mathrm{mmol} / \mathrm{g} \mathrm{DW}\end{array}$ & $\mathrm{K}^{+} / \mathrm{Na}^{+}$Ratio \\
\hline \multirow{3}{*}{ Citrus Yellow } & $0 \mathrm{mM}$ & $6.30 \pm 0.650^{b}$ & $0.066 \pm 0.016^{a}$ & $0.692 \pm 0.007^{b}$ & $0.179 \pm 0.002^{b}$ & 0.259 \\
\hline & $150 \mathrm{mM}$ & $5.99 \pm 0.588^{b}$ & $0.062 \pm 0.017^{\mathrm{a}}$ & $1.602 \pm 0.097^{\mathrm{a}}$ & $0.333 \pm 0.020^{\mathrm{a}}$ & 0.208 \\
\hline & $200 \mathrm{mM}$ & $12.15 \pm 5.24^{\mathrm{a}}$ & $0.036 \pm 0.017^{\mathrm{a}}$ & $1.663 \pm 0.129^{a}$ & $0.345 \pm 0.027^{\mathrm{a}}$ & 0.208 \\
\hline
\end{tabular}


Table 2. Cont.

\begin{tabular}{|c|c|c|c|c|c|c|}
\hline Wheat Cultivars ${ }^{1}$ & $\begin{array}{l}\text { Salinity Level } \\
(\mathrm{mM} \mathrm{NaCl})\end{array}$ & $\begin{array}{c}\text { Water Content } \\
\left(\mathrm{g} \mathrm{H}_{2} \mathrm{Og}^{-1} \mathrm{DW}\right)\end{array}$ & $\begin{array}{c}\text { Total Dry } \\
\text { Weight (g/plant) }\end{array}$ & $\begin{array}{c}\mathrm{Na}^{+} \\
\mathrm{mmol} / \mathrm{g} \mathrm{DW}\end{array}$ & $\begin{array}{c}\mathrm{K}^{+} \\
\mathrm{mmol} / \mathrm{g} \mathrm{DW}\end{array}$ & $\mathrm{K}^{+} / \mathrm{Na}^{+}$Ratio \\
\hline \multirow{3}{*}{ KM 53-14 Blue } & $0 \mathrm{mM}$ & $5.96 \pm 1.50^{\mathrm{a}}$ & $0.039 \pm 0.019^{a}$ & $0.918 \pm 0.085^{b}$ & $0.238 \pm 0.022^{b}$ & 0.259 \\
\hline & $150 \mathrm{mM}$ & $6.92 \pm 0.341^{\mathrm{a}}$ & $0.043 \pm 0.016^{\mathrm{a}}$ & $2.582 \pm 0.080^{a}$ & $0.508 \pm 0.016^{\mathrm{a}}$ & 0.197 \\
\hline & $200 \mathrm{mM}$ & $6.47 \pm 5.04^{\mathrm{a}}$ & $0.034 \pm 0.012^{\mathrm{a}}$ & $2.272 \pm 0.162^{a}$ & $0.447 \pm 0.032^{a}$ & 0.197 \\
\hline \multirow{3}{*}{ KM 178-14 Purple } & $0 \mathrm{mM}$ & $6.86 \pm 0.91^{b}$ & $0.038 \pm 0.010^{\mathrm{a}}$ & $0.643 \pm 0.054^{c}$ & $0.148 \pm 0.012^{c}$ & 0.231 \\
\hline & $150 \mathrm{mM}$ & $4.65 \pm 1.66^{b}$ & $0.042 \pm 0.011^{\mathrm{a}}$ & $2.606 \pm 0.138^{a}$ & $0.455 \pm 0.024^{\mathrm{a}}$ & 0.175 \\
\hline & $200 \mathrm{mM}$ & $9.92 \pm 2.79^{a}$ & $0.056 \pm 0.009^{a}$ & $1.597 \pm 0.093^{b}$ & $0.295 \pm 0.017^{\mathrm{b}}$ & 0.185 \\
\hline \multirow{3}{*}{$\begin{array}{l}\text { Skorpion Blue } \\
\text { Aleurone }\end{array}$} & $0 \mathrm{mM}$ & $22.11 \pm 5.88^{a}$ & $0.027 \pm 0.012^{b}$ & $0.664 \pm 0.074^{b}$ & $0.153 \pm 0.017^{b}$ & 0.185 \\
\hline & $150 \mathrm{mM}$ & $5.63 \pm 0.38^{c}$ & $0.049 \pm 0.010^{b}$ & $1.636 \pm 0.093^{\mathrm{a}}$ & $0.302 \pm 0.017^{\mathrm{a}}$ & 0.185 \\
\hline & $200 \mathrm{mM}$ & $3.98 \pm 0.93^{b}$ & $0.094 \pm 0.025^{a}$ & $1.791 \pm 0.090^{\mathrm{a}}$ & $0.331 \pm 0.017^{\mathrm{a}}$ & 0.231 \\
\hline \multirow{3}{*}{ PS Karkulka } & $0 \mathrm{mM}$ & $6.62 \pm 1.73^{b}$ & $0.046 \pm 0.017^{\mathrm{a}}$ & $0.633 \pm 0.023^{c}$ & $0.146 \pm 0.005^{b}$ & 0.231 \\
\hline & $150 \mathrm{mM}$ & $4.69 \pm 0.46^{b}$ & $0.053 \pm 0.011^{\mathrm{a}}$ & $1.634 \pm 0.093^{b}$ & $0.301 \pm 0.017^{\mathrm{a}}$ & 0.185 \\
\hline & $200 \mathrm{mM}$ & $10.10 \pm 3.67^{\mathrm{a}}$ & $0.069 \pm 0.020^{\mathrm{a}}$ & $1.972 \pm 0.063^{\mathrm{a}}$ & $0.345 \pm 0.011^{\mathrm{a}}$ & 0.175 \\
\hline
\end{tabular}

${ }^{1}$ Values are mean \pm S.E. for six replicates. Statistically significant differences among treatments at each time within one genotype are indicated by different small letters $(p<0.05)$.

\section{Discussion}

In the present research, to discover the development of adaptive responses of different wheat genotypes under salt stress, non-destructive chlorophyll fluorescence techniques were used for the screening of biologically active compounds of a phenolic nature and some photosynthesis parameters. The majority of published vegetation indices for non-invasive remote sensing techniques are not responsive to fast changes in the status of plant photosynthesis under the effects of common environmental stressors [30]. The SFR index is connected with chlorophyll concentration in the leaves [27]. It was shown that under salt stress the SFR values at the first stage of treatment with a concentration of $100 \mathrm{mM}$ in the two coloured genotypes, KM 178-14 purple and Skorpion Blue aleurone found no significant changes compared to the control. However, at the second stage of treatment, with increasing salt concentration, the SFR value decreased.

The level of photosynthetic pigments can be reduced under the effect of different stressful environments [30]. Plus the kinetics of pigments accumulation can be different at the two investigated developmental stages like 2-d-old and 10-d-old leaves [31] with differences between control variants at two investigated stages. The difference in salt tolerance may be connected with plant ontogenetic stages and plant species. Photosynthetic ability is significantly decreased in plants under salinity stress, which affects plant growth and development [32]. Decreasing photosynthetic ability by increased salt stress was connected to the inhibition of carbon uptake via specific metabolic processes, changes in photochemical capacity, lower stomatal conductance or a combination of these factors [33-35].

Flavonol accumulation, which is also a part of the adaptive reaction to salt stress, was observed after the first stage of treatment with $\mathrm{NaCl}(100 \mathrm{mM}$ and $150 \mathrm{mM})$. After the second stage of treatment with $150 \mathrm{mM}$ and $200 \mathrm{mM} \mathrm{NaCl}$, we found a significant difference in the flavonol reaction between the coloured wheat genotypes (with higher anthocyanins content in grains) and non-coloured (with higher carotenoids content in grains). The FLAV and MFI indices have shown a similar dose-dependent tendency of flavonol content increase after the second stage of treatment in the coloured wheat genotypes. The grains of these wheat genotypes have been characterized by the presence of anthocyanins as well [36].

Intensive detoxification of reactive oxygen species (ROS) is a key factor in improving the tolerance of plants to salinity effects. An analysis of phenylpropanoid metabolism at the gene and enzyme levels showed that oxidative damage was lower when flavonols accumulated to a higher degree [37]. Therefore, the higher flavonol accumulation in coloured wheat genotypes (KM 178-14 purple and Skorpion Blue aleurone) showed faster development of adaptive responses to salt stress.

It was estimated that high contents of proline and anthocyanin support an active protective response to salinity [28]. At the first and second stages of salt treatment the coloured wheat genotypes characterized by higher anthocyanin content show increasing proline content. After first treatment 
the wheat genotypes KM 178-14 purple shows the highest increase in proline content. At the second stage of treatment with a concentration of $200 \mathrm{mM} \mathrm{NaCl}$ all experimental genotypes showed increased proline content.

Some studies have cited that the build-up of amino acid proline is an essential regulatory factor under salt stress and may be one of the mechanisms underlying their higher salt tolerance [38-40]. Matysik et al. (2002) showed that proline mitigates salt stress-induced increases in the carboxylase and oxygenase activities of Rubisco [41]. It protects plants from ROS damage by suppressing singlet oxygen. The early responses to salt and water stress have been found to be mostly equal [42]. Slama et al. (2015) found that in plants grown under salt stress, the elevation of the synthesis of proline can be regarded as an adaptation strategy in this species when exposed to salt stress [10]. Organic osmolytes can indirectly participate in osmotic adjustment by changing $\mathrm{K}^{+}$flow across membranes, thus reducing sodium-induced efflux of such inorganic osmolytes [42].

Increased lipid peroxidation (LP) and proline contents were observed to significantly accumulate in barley and Catharanthus roseus seedlings under salinity effects $[43,44]$. LP process changes depend on plant sensitivity and the degree of influence stressor. The effect of increasing $\mathrm{NaCl}$ doses on the accumulation of proline and LP can result in their high correlation with the tolerance capacity of plant cultivars $[45,46]$. Low MDA values, as an important indicator of a high oxidative damage-limiting capacity, were shown to be important for tolerating the salinity $[46,47]$.

The results of our experiment showed the different development of an LP process in different wheat genotypes. It was found that in salt-stressed seedlings, MDA contents were negatively correlated with the accumulation of proline and total anthocyanins [27,47]. The results of the experimental work on seedings have shown that Citrus yellow and KM 53-14 Blue cultivars were salt-stress sensitive genotypes compared to other tested varieties. Different changes in MDA, proline and anthocyanin accumulations under salt stress have been observed for coloured and non-coloured wheat genotypes. It can provide evidence for the development of adaptive responses under salt stress the wheat genotypes tested in the experiment.

The tolerant genotypes of wheat showed a better capacity to maintain the low accumulation of $\mathrm{Na}^{+}$, higher shoot $\mathrm{K}^{+}$concentrations, stable osmotic potential, increased values of PSII activity, lower non-photochemical quenching (NPQ) and maximal photochemical efficiency derived in the significantly greater dry weight production detected under salt stress $[25,26]$. Low $\mathrm{Na}^{+}$accumulation in leaf can be used as the best screening criteria, employing a large set of genotypes in a breeding program [48]. The dry weight of shoot biomass after salt stress influence increased again in Skorpion blue aleurone and PS Karkulka. The genotype Citrus yellow, with lower anthocyanin content, was characterized by a decrease in dry weight under both $\mathrm{NaCl}$ concentrations.

The content of $\mathrm{Na}^{+}$and $\mathrm{K}^{+}$obtained at different levels of salinity on the basis of DW was more than three times greater than the control, with a significant increase of both ions under salt stress. Cramer et al. (1985) demonstrated that in the presence of high $\mathrm{NaCl}$ concentrations, $\mathrm{Na}{ }^{+}$moves $\mathrm{Ca}$ from the plasmalemma of root cells, resulting in increased membrane permeability that causes $\mathrm{K}$ efflux and alteration of the selectivity ratio $\mathrm{K}^{+} / \mathrm{Na}^{+}$[49]. This suggests that plants that are successfully grown in saline conditions are those that maintain a higher $\mathrm{K}^{+} / \mathrm{Na}^{+}$ratio in their cytoplasm than in the rhizosphere [50].

The toxicity of excessive salt on the cell level corresponds to the $\mathrm{Na}^{+}$level accumulated in the cells [51]. In plants, $\mathrm{K}^{+}$is engaged in cell metabolism, photosynthesis, and protein synthesis and is also essential for regulating enzyme activation and stomatal movement [52]. The regulation of $\mathrm{Na}^{+}$uptake and support of the relative $\mathrm{Na}^{+} / \mathrm{K}^{+}$ratio can be recognized as an important cellular mechanism that assists plant adaptation to saline environments [53].

Siddiqui et al. (2017) obtained similar results regarding $\mathrm{Na}^{+}$ions. In the wheat leaves of 10 cultivars, significant increases in $\mathrm{Na}^{+}$content, but decreases in $\mathrm{K}^{+}$content were found under salinity stress conditions [54]. The ratio of $\mathrm{Na}^{+} / \mathrm{K}^{+}$was significantly increased at all $\mathrm{NaCl}$ concentrations. The different plant genotypes reveal different salt tolerance mechanisms. These mechanisms are all 
based on the function and regulation of $\mathrm{K}^{+}$and $\mathrm{Na}^{+}$transporters and $\mathrm{H}^{+}$pumps, which create the driving force for $\mathrm{K}^{+}$and $\mathrm{Na}^{+}$transport $[55,56]$. It can be concluded that the contribution of $\mathrm{Na}^{+}$and $\mathrm{K}^{+} / \mathrm{H}^{+}$antiporter proteins to plant salt stress tolerance is involved in $\mathrm{K}^{+}$homeostasis support rather than $\mathrm{Na}^{+}$sequestration into the vacuole.

The water content (WC) increased at high doses of $\mathrm{NaCl}$ under both treatment levels. During the growth phase and after salt application, the WC was effectively protected. This content is one of the key indicators of plant water status. Relative turgidity was less affected by stress and reflects good efficiency in saving water. This improvement can be explained, in part, by the effective accumulation of organic osmolytes, which suggests that the existence of mechanisms of osmotic adjustment lead to the protection of the structural and functional integrity of the tissue [10]. On the other hand, the improvement of the water status of plants may be, in part, a consequence of the lack of a significant reduction in stomatal conductance. It was found that salinity significantly reduced root hydraulic conductance [57]. In contrast, in cotton and common bean, WC decreased with salt stress at low rates of salt (50 $\mathrm{mM})$ due to osmotic adjustment and a decrease in transpiration [58].

\section{Materials and Methods}

\subsection{Plant Material}

Seeds of five wheat genotypes (Triticum sp.) with different pigments (Citrus yellow, KM 53-14 Blue, KM 178-14 purple, Skorpion Blue aleurone, and PS Karkulka purple) were provided by the Agricultural Research Institute Kromeriz, Kromeriz, Czech Republic, respectively. The characteristics of coloured grains were based on the visual pink, blue and yellow colour assessment (Figure 6).
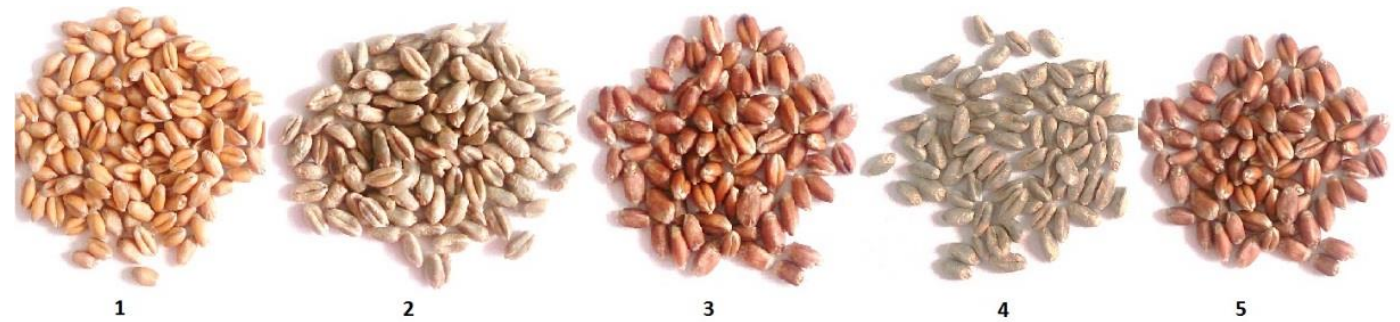

Figure 6. Coloured wheat seeds of the genotypes used in experiments 1-Citrus yellow, 2-KM 53-14 Blue, 3-KM 178-14 purple, 4-Skorpion Blue aleurone, 5-PS Karkulka purple.

Coloured grains have blue aleurone (Ba genes), purple pericarp (Pp genes) and yellow endosperm (Psy genes), which are determined by the presence of anthocyanins and carotenoids [59]. The blue aleurone (Ba genes) pericarp got grains of KM 53-14 Blue and Skorpion Blue aleurone wheat genotype. The purple pericarp (Pp genes) got grains of KM 178-14 purple and PS Karkulka purple wheat genotype. The yellow endosperm (Psy genes) have grains of Citrus yellow wheat genotype.

\subsection{Growth Conditions}

Sterile sandy soil of fine texture was filled in plastic pots $(12 \mathrm{~cm}$ diameter $)$ to conduct culture under controlled conditions. Grains were washed extensively with distilled water and sterilized with $5 \%$ sodium hypochlorite for $5 \mathrm{~min}$. Then, seeds were sown in sandy soil directly watered with $3 \mathrm{~mL}$ of $1 / 4$ strength Hoagland's nutrient solution [60]. The germination process was under controlled conditions of $25 \pm 2{ }^{\circ} \mathrm{C}$. The controlled growing conditions in a growing chamber had the following parameters: relative humidity of $60-70 \%$ and light/dark regime of $16 / 8 \mathrm{~h}$ at $25 / 20{ }^{\circ} \mathrm{C}$. Four pots per treatment with 6 plants per pot were harvested after 30 days of the experiment. Pots were irrigated every three days, alternatively with filtrated water and a nutrient solution, according to Etherton (1963) [61], until they were 4 weeks old. It was used different concentrations of salinity treatments (0 (Control), 100, 150 and $250 \mathrm{mM} \mathrm{NaCl}$ ). The control plants only received nutrient solution. To avoid 
osmotic shock due to high concentrations, plants were started on lower concentrations 100 and $150 \mathrm{mM}$ $\mathrm{NaCl}$ (first stage of treatment), then the concentration was increased after 5 days with $50 \mathrm{mM} \mathrm{NaCl}$, until wheat genotypes reached the concentration 150 and $200 \mathrm{mM} \mathrm{NaCl}$ (second stage of treatment). Tap water was used daily to balance the water presence after evaporative loss in plant seedlings.

\subsection{Growth Parameters}

After harvest, the shoot fresh weight (FW) was measured. The dry weight (DW) was estimated after putting plant samples in a forced-draft oven at $60^{\circ} \mathrm{C}$ for $48 \mathrm{~h}$ or until a fixed weight was obtained.

$$
\text { Water content }\left(\mathrm{g} \mathrm{H}_{2} \mathrm{Og}^{-1} \mathrm{DW}\right)=(\mathrm{FW}-\mathrm{DW}) / \mathrm{DW}
$$

\subsection{Chlorophyll Fluorescence Records and Analyses Using the Fluorescence Excitation Ratio Method}

Chlorophyll fluorescence analysis was performed using the portable optical fluorescence sensor Multiplex- $3^{\circledR}$ (Force-A, Paris, France). Multiplex $-3^{\circledR}$ is a multi-parametric, hand-operated sensor. The determination principle is based on light-emitting-diode excitation and a filtered photodiode. The portable optical fluorescence sensor Multiplex $-3^{\circledR}$ is arranged to work in the laboratory, greenhouse and field conditions. The Multiplex- $3^{\circledR}$ sensor has three red-blue-green LED matrices emitting light at 153 and $635 \mathrm{~nm}$ (red), $470 \mathrm{~nm}$ (blue) and $516 \mathrm{~nm}$ (green). There are three integrated photodiode detectors for fluorescence recording: far-red, red and yellow [29]. The values of fluorescence measured at UV (375 nm), green light $(516 \mathrm{~nm})$, red light $(635 \mathrm{~nm})$ and far-red light $(735 \mathrm{~nm})$ have been used.

The evaluation of phenolic compound contents in plants was performed via the calculation of fluorescence values detected after excitation by light of the defined wavelengths (details are below). Similar to the spectrophotometric method for assessing leaf absorbance, the parameters were based on Beer-Lambert's law and calculated as the logarithm of the fluorescence ratio values.

The UV absorbing compound (mostly flavonol) content described by the flavonoid (FLAV) index [62] was estimated using the modified formula [27] as the logarithm of the ratio of the red-light induced far-red fluorescence $\left(F R F_{R}\right)$ and the UV-induced far-red fluorescence $\left(F R F_{U V}\right)$ :

$$
\mathrm{FLAV}=\log \left[\mathrm{FRF}_{\mathrm{R}} /\left(\mathrm{k}_{\mathrm{UV}} \times \mathrm{FRF}_{\mathrm{UV}}\right)\right]
$$

Similarly, the ANTH Index that provides estimates of green-light absorbing components $\left(\log \mathrm{FER}_{\mathrm{R} / \mathrm{G}}\right)$, mostly red-coloured anthocyanins and flavonoids, was determined as the logarithm of the ratio of the red-light induced fluorescence $\left(F R F_{R}\right)$ and the green light-induced fluorescence $\left(F R F_{G}\right)$ :

$$
\mathrm{ANTH}=\log \left[\mathrm{FRF}_{\mathrm{R}} /\left(\mathrm{k}_{\mathrm{G}} \times \mathrm{FRF}_{\mathrm{G}}\right)\right]
$$

The correction coefficients $\mathrm{k}_{\mathrm{UV}}$ or $\mathrm{k}_{\mathrm{G}}$ were applied to measurements of fluorescence to avoid negative values [27]. The constant values of the coefficients were used as the minimum values of the $\mathrm{FRF}_{\mathrm{UV}} / \mathrm{FRF}_{\mathrm{R}}$ and $\mathrm{FRF}_{\mathrm{G}} / \mathrm{FRF}_{\mathrm{R}}$ ratios found in the database that contains several thousand records from over three hundred plant species grown in diverse environments. The same constants have been used when processing data across all experiments and cultivars. We also calculated the modified flavonoid index (MFI), which provides a better estimate of total flavonoid content when plants with different colours are compared [27]. The logarithm of the ratio of the red-light induced fluorescence $\left(F R F_{R}\right)$ and the green light-induced fluorescence $\left(F R F_{G}\right)$ was used to calculate the MFI parameter.

$$
\mathrm{MFI}=\log \left[2 \times \mathrm{FRF}_{\mathrm{R}} /\left(\mathrm{kG} \times \mathrm{FRF}_{\mathrm{G}}+\mathrm{k}_{\mathrm{UV}} \times \mathrm{FRFU}_{\mathrm{V}}\right)\right]
$$

The values of correction coefficients $\left(\mathrm{k}_{\mathrm{G}}, \mathrm{k}_{\mathrm{UV}}\right)$ for MFI were the same as for ANTH and FLAV. 
Chlorophyll content was estimated from values of fluorescence measured at $735 \mathrm{~nm}$ (FRF) and $685 \mathrm{~nm}(\mathrm{RF})$ after excitation by red light $(635 \mathrm{~nm})$. The simple fluorescence ratio (SFR) was calculated:

$$
\mathrm{SFR}=\mathrm{FRF}_{\mathrm{R}} / \mathrm{RF}_{\mathrm{R}}
$$

Because the diameter of the measuring area was only $50 \mathrm{~mm}, 6-7$ measurements were taken on each plant in different positions to account for heterogeneity in leaf colour and structure. This number of measurements from the top view provides sufficient data to characterize the entire plant. The number of measurements for each plant was 30 .

\subsection{Proline Assay}

The extraction was made by the method of Troll and Lindsley (1955) and simplified based on Wittmer (1987) [63,64]. One hundred milligrams of fresh material was placed with $2 \mathrm{~mL}$ of $40 \%$ methanol. The reaction mixture was heated at $85^{\circ} \mathrm{C}$ in a water bath for $1 \mathrm{~h}$. After cooling, $1 \mathrm{~mL}$ was removed from the extract to which $1 \mathrm{~mL}$ of acetic acid and $1 \mathrm{~mL}$ of the mixture containing $120 \mathrm{~mL}$ distilled water $+300 \mathrm{~mL}$ of ortho-phosphoric acid was added. The resulting solution was boiled for $30 \mathrm{~min}$. After cooling, $5 \mathrm{~mL}$ of toluene was added. Two phases were separated and the upper phase (organic phase) was recovered. Absorbance measurements were determined using a Jenway UV/Vis. 6405 spectrophotometer (Jenway, Chelmsford, UK) at $528 \mathrm{~nm}$. Proline concentration was estimated from a standard curve.

\subsection{Lipid Peroxidation (LP) Assay}

LP in leaves was identified by estimating the malondialdehyde (MDA) concentration [65]. Plant material $\left(0.2 \mathrm{~g}\right.$ ) was homogenized in $3 \mathrm{~mL}$ of $0.1 \mathrm{~mol} \mathrm{~kg}{ }^{-1}$ Tris buffer containing $0.3 \mathrm{~mol} \mathrm{~kg}^{-1}$ $\mathrm{NaCl}$. Two millilitres of $20 \%$ trichloroacetic acid (TCA) containing $0.5 \%$ thiobarbituric acid and $2 \mathrm{~mL}$ of $20 \%$ TCA were added. The mixture was heated at $95{ }^{\circ} \mathrm{C}$ for $30 \mathrm{~min}$. Then, the homogenate was centrifuged at $10,000 \times g$ for $5 \mathrm{~min}$. The absorbance of the supernatant was measured at $532 \mathrm{~nm}$ with use of spectrophotometer Jenway UV/Vis. 6405 (Jenway, Chelmsford, UK).

\subsection{Anthocyanin Estimation}

Plant material $(0.1 \mathrm{~g})$ was soaked in $3 \mathrm{~mL}$ of acidified methanol $(1 \% v / v \mathrm{HCl})$ for $12 \mathrm{~h}$ in darkness at $4{ }^{\circ} \mathrm{C}$ with occasional shaking. The mixture was centrifuged for $10 \mathrm{~min}$ at $14000 \mathrm{rpm}$ at $4{ }^{\circ} \mathrm{C}$. Absorption of the extracts was estimated spectrophotometrically at 530 and $657 \mathrm{~nm}$ wavelengths on spectrophotometer Jenway UV/Vis. 6405 (Jenway, Chelmsford, UK). The blank was acidified methanol. The anthocyanin concentration was revealed as $\mathrm{mg} \cdot \mathrm{g}^{-1} \mathrm{DW}$ and was calculated by the following formula:

$$
\text { Anthocyanins }=[\text { OD530 }-0.25 \text { OD657 }] \times \mathrm{TV} /[\mathrm{d} w \mathrm{t} \times 1000]
$$

$\mathrm{OD}=$ optical density; $\mathrm{TV}=$ total volume of the extract $(\mathrm{mL}) ; \mathrm{d} w \mathrm{t}=$ weight of the dry leaf tissue $(\mathrm{g})$.

\section{8. $\mathrm{Na}^{+}$and $\mathrm{K}^{+}$Accumulation}

Measurements of $\mathrm{Na}^{+}$and $\mathrm{K}^{+}$accumulation in the flag leaf were carried out 3 days after flowering. Oven-dried simple flag leaves were finely ground before passing through a 2-mm sieve. Samples $(0.5 \mathrm{~g})$ were mixed with $10 \mathrm{~mL}$ of concentrated nitric acid and $3 \mathrm{~mL}$ of perchlorate acid in digesting tubes for $12 \mathrm{~h}$ and then dissolved at $300{ }^{\circ} \mathrm{C}$ for $6 \mathrm{~h}$. The concentration of $\mathrm{K}^{+}$and $\mathrm{Na}^{+}$was detected using an atomic absorption spectrophotometer (Sherwood 410, Cambridge, UK).

\subsection{Statistical Analysis}

Statistical analyses were performed using two factor (genotype $x$ salt concentration) analysis of variance (ANOVA) and Duncan's multiple range test performed at $p=0.05$ (STATISTICA 10, StatSoft, 
Tulsa, OK, USA). Two terms of measurements were analysed separately. Mean values were calculated from six plants per cultivar in each experimental variant. Data are presented as mean \pm standard error from six replicates (SE).

\section{Conclusions}

In the presented work has been presented the role of anthocyanins in the development salt tolerant stress responses in wheat plants. The coloured wheat genotypes, which were used as models to study the role of anthocyanins in the development of adaptive response to salt stress, may be used in the farther agricultural cultivation practices. It was found that higher flavonol and anthocyanin accumulation in coloured wheat genotypes showed a faster development of adaptive responses of wheat genotypes to salt stress. Furthermore, the KM 178-14 purple, Skorpion blue aleurone, and PS Karkulka, genotypes demonstrated an increased content of anthocyanins, proline and flavonol in the presence of $\mathrm{NaCl}$ and are more salt tolerant than Citrus yellow and $\mathrm{KM} 53-14 \mathrm{Blue}$, as most of the parameters (especially growth) were rarely influenced or affected by the use of $150 \mathrm{mM} \mathrm{NaCl}$.

Author Contributions: S.M. and O.S. conceived and designed the experiments; M.Z. and A.C. performed the experiments; S.M. and O.S. wrote the paper; M.B. and A.C. reviewed and corrected the document.

Funding: This research was funded by Slovak Research and Development Agency under the project APVV-15-0721 and the Scientific Grant Agency of Ministry of Education, Slovak Republic under the project 1, VEGA 1-0923-16.

Acknowledgments: We thank Mark Kovar for his help and support during experiment.

Conflicts of Interest: The authors declare no conflict of interest. The founding sponsors had no role in the design of the study; in the collection, analyses, or interpretation of data; in the writing of the manuscript, and in the decision to publish the results.

\section{References}

1. Gibbs, H.K.; Salmon, J.M. Mapping the world's degraded lands. Appl. Geogr. 2015, 57, 12-21. [CrossRef]

2. Geist, H. The Causes and Progression of Desertification; Routledge: London, UK, 2017.

3. Lachhab, I.; Louahlia, S.; Laamarti, M.; Hammani, K. Effet d'un stress salin sur la germination et l'activité enzymatique chez deux génotypes de Medicago sativa. Int. J. Innov. Appl. Stud. 2013, 3, 511-516.

4. FAO. FAOSTAT. Online Statistical Database. 2016. Available online: http://faostat.fao.org/ (accessed on 30 July 2016).

5. Minhas, P.S. Edaphic stresses: Concerns and opportunities for management. In Abiotic Stress Management for Resilient Agriculture; Minhas, P.S., Rane, J., Pasala, R.K., Eds.; Springer: Singapore, 2017.

6. Munns, R.; Tester, M. Mechanisms of salinity tolerance. Ann. Rev. Plant Biol. 2008, 59, 651-681. [CrossRef] [PubMed]

7. Wang, Z.S.; Li, X.N.; Zhu, X.C.; Liu, S.Q.; Song, F.B.; Liu, F.L.; Wang, Y.; Qi, X.N.; Wang, F.H.; Zuo, Z.Y.; et al. Salt acclimation induced salt tolerance is enhancedby abscisic acid priming in wheat. Plant Soil Environ. 2017, 63, 307-314.

8. Mbarki, S.; Cerdà, A.; Zivcak, M.; Brestic, M.; Rabhi, M.; Mezni, M.; Abdelly, C.; Pascual, J.A. Alfalfa crops amended with MSW compost can compensate the effect of salty water irrigation depending on the soil texture. Process Saf. Environ. Prot. 2018, 115, 8-16. [CrossRef]

9. Sharifi, R.S.; Khalilzadeh, R.; Jalilian, J. Effects of biofertilizers and cycocel on some physiological and biochemical traits of wheat (Triticum aestivum L.) under salinity stress. Arch. Agron. Soil Sci. 2016, 63, 308-318. [CrossRef]

10. Slama, I.; Abdelly, C.; Bouchereau, A.; Flowers, T.; Savoure, A. Diversity, distribution and roles of osmoprotective compounds accumulated in halophytes under abiotic stress. Ann. Bot. 2015, 115, $433-447$. [CrossRef] [PubMed]

11. El Midaoui, M.; Benbella, M.; Ait Houssa, A.; Ibriz, M.; Talouizte, A. Contribution to the study of some mechanisms of adaptation to salinity in cultivated sunflower (Helianthus annuus L.). Revue HTE 2007, 136, 29-34.

12. Hamed, K.B.; Chibani, F.; Abdelly, C.; Magne, C. Growth, sodium uptake and antioxidant responses of coastal plants differing in their ecological status under increasing salinity. Biologia 2014, 69, 193-201. 
13. Zhu, J.K. Regulation of ion homeostasis under salt stress. Curr. Opin. Plant Biol. 2003, 6, 441-445. [CrossRef]

14. Liang, W.; Ma, X.; Wan, P.; Liu, L. Plant salt-tolerance mechanism: A review. Biochem. Biophys. Res. Commun. 2018, 495, 286-291. [CrossRef] [PubMed]

15. Mahajan, S.; Tuteja, N. Cold, salinity and drought stresses: An overview. Arch. Biochem. Biophys. 2005, 444, 139-158. [CrossRef] [PubMed]

16. Parida, A.K.; Das, A.B. Salt tolerance and salinity effects on plants: A review. Ecotoxicol. Environ. Saf. 2005, 60, 324-349. [CrossRef] [PubMed]

17. Dardanelli, M.S.; Fernández de Córdoba, F.J.; Espuny, M.R.; Rodríguez Carvajal, M.A.; Soria Díaz, M.E.; Gil Serrano, A.M.; Yaacov, O.; Megías, M. Effect of Azospirillum brasilense coinoculated with Rhizobium on Phaseolus vulgaris flavonoids and Nod factor production under salt stress. Soil Biol. Biochem. 2008, 40, 2713-2721. [CrossRef]

18. Daneshmand, F.; Arvin, M.J.; Kalantari, K.M. Physiological responses to $\mathrm{NaCl}$ stress in three wild species of potato in vitro. Acta Physiol. Plant 2010, 32, 91-101. [CrossRef]

19. Posmyk, M.M.; Kontek, R.; Janas, K.M. Antioxidant enzymes activity and phenolic compounds content in red cabbage seedlings exposed to copper stress. Ecotoxicol. Environ. Saf. 2009, 72, 596-602. [CrossRef] [PubMed]

20. Kondo, T.; Yoshida, K.; Nakagawa, A.; Kawai, T.; Tamura, H.; Goto, T. Commelinin, a highly associated metalloanthocyanin present in the blue flower petals of Commelina communis. Nature 1992, 358, 515-517.

21. Shannon, M.C.; Grieve, C.M. Tolerance of vegetable crops to salinity. Scientia Hortic. 1999, 78, 5-38. [CrossRef]

22. Ngara, R.; Ndimba, R.; Jensen, J.B.; Jensen, O.N.; Ndimb, B. Identification and profiling of salinity stress-responsive proteins in Sorghum bicolor seedlings. J. Proteomics 2012, 75, 4139-4150. [CrossRef] [PubMed]

23. Caverzan, A.; Casassola, A.; Brammer, S.P. Antioxidant responses of wheat plants under stress. Genet. Mol. Biol. 2016, 39, 1-6. [CrossRef] [PubMed]

24. Ksouri, R.; Megdiche, W.; Debez, A.; Falleh, H.; Grignon, C.; Abdelly, C. Salinity effects on polyphenol content and antioxidant activities in leaves of the halophyte Cakile maritima. Plant Physiol. Biochem. 2007, 45, 244-249. [CrossRef] [PubMed]

25. Oyiga, B.C.; Sharma, R.C.; Shen, J.; Baum, M.; Ogbonnaya, F.C.; Léon, J.; Ballvora, A. Identification and characterization of salt tolerance of wheat germplasm using a multivariable screening approach. J. Agron. Crop Sci. 2016, 202, 472-485. [CrossRef]

26. Kalhoro, N.A.; Rajpar, I.; Kalhoro, S.A.; Ali, A.; Raza, S.; Ahmed, M.; Kalhoro, F.A.; Ramzan, M.; Wahid, F. Effect of salts stress on the growth and yield of wheat (Triticum aestivum L.). Am. J. Plant Sci. 2016, 7, 2257-2271. [CrossRef]

27. Zivcak, M.; Brückova, K.; Sytar, O.; Brestic, M.; Olsovska, K.; Allakhverdiev, S.I. Lettuce flavonoids screening and phenotyping by chlorophyll fluorescence excitation ratio. Planta 2017, 245, 1215-1229. [CrossRef] [PubMed]

28. Chutipaijit, S.; Chaum, S.; Sompornpailin, K. High contents of proline and anthocyanin increase protective response to salinity in Oryza sativa L. spp. indica. Aust. J. Crop Sci. 2011, 5, 1191-1198.

29. Gaweł, S.; Wardas, M.; Niedworok, E.; Wardas, P. Malondialdehyde (MDA) as a lipid peroxidation marker. Wiad Lek. 2004, 57, 453-455. [PubMed]

30. Ghozlen, N.B.; Cerovic, Z.G.; Germain, C.; Toutain, S.; Latouche, G. Non-destructive optical monitoring of grape maturation by proximal sensing. Sensors 2010, 10, 10040-10068. [CrossRef] [PubMed]

31. Schoefs, B.; Bertrand, M.; Lemoine, Y. Changes in the photosynthetic pigments in bean leaves during the first photoperiod of greening and the subsequent dark-phase. Comparison between old (10-d-old) leaves and young (2-d-old) leaves. Photosynth. Res. 1998, 57, 203. [CrossRef]

32. Ashraf, M.; Harris, P.J.C. Photosynthesis under stressful environments: An overview. Photosynthetica 2013, 51, 163-190. [CrossRef]

33. Ashraf, M. Some important physiological selection criteria for salt tolerance in plants. Flora 2004, 199, 361-376. [CrossRef]

34. Dubey, R.S. Photosynthesis in plants under stressful conditions. In Hand Book Photosynthesis, 2nd ed.; Pessarakli, M., Ed.; C.R.C. Press: New York, NY, USA, 2005; pp. 717-718.

35. Ashraf, M.; Foolad, M.R. Roles of glycinebetaine and proline in improving plant abiotic stress resistance. Environ. Exp. Bot. 2007, 59, 206-216. [CrossRef] 
36. Abdel-Aal, E.S.M.; Hucl, P. Composition and stability of anthocyanins in blue-grained wheat. J. Agric. Food Chem. 2003, 51, 2174-2180. [CrossRef] [PubMed]

37. Knievel, D.C.; Abdel-Aal, E.S.M.; Rabalski, I.; Nakamura, T.; Hucl, P. Grain color development and the inheritance of high anthocyanin blue aleurone and purple pericarp in spring wheat (Triticum aestivum L.). J. Cereal Sci. 2009, 50, 113-120. [CrossRef]

38. Martinez, V.; Mestre, T.C.; Rubio, F.; Girones-Vilaplana, A.; Moreno, D.A.; Mittler, R.; Rivero, R.M. Accumulation of flavonols over hydroxycinnamic acids favors oxidative damage protection under abiotic stress. Front. Plant Sci. 2016, 7, 838. [CrossRef] [PubMed]

39. Huang, Z.; Zhao, L.; Chen, D.; Liang, M.; Liu, Z.; Shao, H.; Long, X. Salt stress encourages proline accumulation by regulating proline biosynthesis and degradation in Jerusalem artichoke plantlets. PLOS ONE 2013, 8, e62085. [CrossRef] [PubMed]

40. Shirazi, M.; Khan, M.; Mahboob, W.; Khan, M.A.; Shereen, A.; Mujtaba, S.; Asad, A. Inconsistency in salt tolerance of some wheat (Triticum aestivium L.) genotypes evaluated under various growing environments. Pak. J. Bot. 2018, 50, 471-479.

41. Matysik, J.; Alia, T.A.; Bhalu, B.A.; Mohanty, P. Molecular mechanisms of quenching of reactive oxygen species by proline under stress in plants. Curr. Sci. 2002, 82, 525-532.

42. Munns, R. Comparative physiology of salt and water stress. Plant Cell Environ. 2002, 25, 239-250. [CrossRef] [PubMed]

43. Cuin, T.A.; Shabala, S. Amino acids regulate salinity-induced potassium efflux in barley root epidermis. Planta 2007, 225, 753-761. [CrossRef] [PubMed]

44. Jaleel, C.A.; Gopi, R.; Sankar, B.; Manivannan, P.; Kishorekumar, A.; Sridharan, R.; Panneerselvam, R. Studies on germination, seedling vigour, lipid peroxidation and proline metabolism in Catharanthus roseus seedlings under salt stress. S. Afr. J. Bot. 2007, 73, 190-195. [CrossRef]

45. Shabala, S.; Cuin, T.A. Potassium transport and plant salt tolerance. Physiol. Plant. 2008, 133, 651-669. [CrossRef] [PubMed]

46. Koca, H.; Melike, B.; Özdemir, F.; Türkan, İ. The effect of salt stress on lipid peroxidation, antioxidative enzymes and proline content of sesame cultivars. Environ. Exp. Bot. 2007, 60, 344-351. [CrossRef]

47. Feki, K.; Tounsi, S.; Brini, F. Comparison of an antioxidant system in tolerant and susceptible wheat seedlings in response to salt stress. Span. J. Agric. Res. 2018, 15, 0805. [CrossRef]

48. Saddiq, M.S.; Afzal, I.; Basra, S.M.; Ali, Z.; Ibrahim, A.M. Sodium exclusion is a reliable trait for the improvement of salinity tolerance in bread wheat. Arch. Agron. Soil Sci. 2018, 64, 272-284. [CrossRef]

49. Cramer, G.R.; Läuchli, A.; Polito, V.S. Displacement of $\mathrm{Ca}^{2+}$ by $\mathrm{Na}^{+}$from the plasmalemma of root cells: A primary response to salt stress? Plant Physiol. 1985, 79, 207-211. [CrossRef] [PubMed]

50. El-Iklil, Y.; Karrou, M.; Benichou, M. Salt stress effect on epinasty in relation to ethylene production and water relations in tomato. Agronomy 2000, 20, 399-406. [CrossRef]

51. Zafar, S.A.; Shokat, S.; Ahmed, H.G.M.; Khan, A.; Ali, M.Z.; Atif, R.M. Assessment of salinity tolerance in rice using seedling-based morpho-physiological indices. Adv. Life Sci. 2015, 2, 142-149.

52. Nievens-Cordones, M.; Al Shiblawi, F.R.; Sentenac, H. Role and transport of sodium and potassium in plants. Met. Ions Life Sci. 2016, 16, 291-324.

53. Munns, R.; James, R.A.; Islam, A.K.M.R.; Colmer, T.D. Hordeum marinum-wheat amphiploids maintain higher leaf $\mathrm{K}^{+}: \mathrm{Na}^{+}$and suffer less leaf injury than wheat parents. Plant Soil 2011, 348, 365-377. [CrossRef]

54. Siddiqui, M.N.; Mostofa, M.G.; Akter, M.M.; Srivastava, A.K.; Sayed, M.A.; Hasan, M.S.; Tran, L.P. Impact of salt-induced toxicity on growth and yield-potential of local wheat cultivars: Oxidative stress and ion toxicity are among the major determinants of salt-tolerant capacity. Chemosphere 2017, 187, 385-394. [CrossRef] [PubMed]

55. Almeida, D.M.; Oliveira, M.M.; Saibo, N.J.M. Regulation of $\mathrm{Na}^{+}$and $\mathrm{K}^{+}$homeostasis in plants: Towards improved salt stress tolerance in crop plants. Genet. Mol. Biol. 2017, 40, 326-345. [CrossRef] [PubMed]

56. Maathuis, F.J.; Ahmad, I.; Patishtan, J. Regulation of $\mathrm{Na}\left(^{+}\right)$fluxes in plants. Front. Plant Sci. 2014, 5, 467. [CrossRef] [PubMed]

57. Silva, C.; Martinez, V.; Carvajal, M. Osmotic versus toxic effects of $\mathrm{NaCl}$ on pepper plants. Biol. Plant 2008, 52, 72-79. [CrossRef] 
58. Kadri, A.; Madiouni, N. Effet du stress salin sur quelques paramètres biochimiques de la luzerne cultivée (Medicago sativa L.) Mémoire En vue de l'obtention du diplôme de Master Academique. Master's Thesis, University of Ouargla, Ouargla, Algeria, 4 June 2015.

59. Martinek, P.; Jirsa, O.; Vaculová, K.; Chrpová, J.; Watanabe, N.; Burešová, V.; Kopecký, D.; Štiasna, K.; Vyhnánek, T.; Trojan, V. Use of wheat gene resources with different grain colour in breeding. In Proceedings of the 64 Tagung der Vereinigung der Pflanzenzüchter und Saatgutkaufleute Österreichs, Raumber-Gumpenstein, Austria, 25-26 November 2013; pp. 75-78.

60. Epstein, E. Mineral Nutrition of Plants: Principles and Perspectives; John Wiley and Sons, Inc.: New York, NY, USA, 1972; 412p.

61. Etherton, B. Relationship of cell transmembrane electropotential to potassium and sodium accumulation ratios in oat and pea seedlings. Plant Physiol. 1963, 38, 581-585. [CrossRef] [PubMed]

62. Agati, G.; Cerovic, Z.G.; Pinelli, P.; Tattini, M. Light-induced accumulation of ortho-dihydroxylated flavonoids as non-destructively monitored by chlorophyll fluorescence excitation techniques. Environ. Exp. Bot. 2011, 73, 3-9. [CrossRef]

63. Troll, W.; Lindsley, J. A photometric method for the determination of proline. J. Biol. Chem. 1955, 215, 655-660. [PubMed]

64. Wittmer, G. Osmotic and elastic adjustment of durum wheat leaves under drought stress conditions. Genet. Agrar. 1987, 41, 427-436.

65. Heath, R.L.; Packer, L. Photoperoxidation in isolated chloroplasts 1. Kinetics and stoichiometry of fatty acid peroxidatoin. Arch. Biochem. Biophys. 1968, 125, 189-198. [CrossRef]

Sample Availability: Samples of the compounds are not available from the authors.

(C) 2018 by the authors. Licensee MDPI, Basel, Switzerland. This article is an open access article distributed under the terms and conditions of the Creative Commons Attribution (CC BY) license (http://creativecommons.org/licenses/by/4.0/). 